Research Article

\title{
Small-Scale Variability in the Soil Microbial Community Structure in a Semideveloped Farm in Zambia
}

\author{
Toru Hamamoto $\mathbb{D}^{1},{ }^{1}$ Meki Chirwa, ${ }^{2}$ Imasiku Nyambe, ${ }^{3}$ and Yoshitaka Uchida $\mathbb{D}^{4}$ \\ ${ }^{1}$ Graduate School of Agriculture, Hokkaido University, Kita 9 Nishi 9 Kita-Ku, Sapporo, Hokkaido 060-8589, Japan \\ ${ }^{2}$ Geology Department, University of Zambia, 10101 Lusaka, Zambia \\ ${ }^{3}$ Integrated Water Resources Management Center, Geology Department, University of Zambia, 10101 Lusaka, Zambia \\ ${ }^{4}$ Research Faculty of Agriculture, Hokkaido University, Kita 9 Nishi 9 Kita-Ku, Sapporo, Hokkaido 060-8589, Japan \\ Correspondence should be addressed to Toru Hamamoto; hamatoru@chem.agr.hokudai.ac.jp
}

Received 3 October 2017; Accepted 23 January 2018; Published 15 March 2018

Academic Editor: Oliver Dilly

Copyright ( $) 2018$ Toru Hamamoto et al. This is an open access article distributed under the Creative Commons Attribution License, which permits unrestricted use, distribution, and reproduction in any medium, provided the original work is properly cited.

\begin{abstract}
The conversion of natural lands into agricultural lands can lead to changes in the soil microbial community structure which, in turn, can affect soil functions. However, few studies have examined the effect of land use changes on the soil microbial community structure in sub-Saharan Africa. Therefore, the aim of this research was to investigate the relationships among soil characteristics and microbial communities in natural and agricultural ecosystems in a semideveloped lowland farm in the central region of Zambia, within which small-scale wetlands had been partly developed as watermelon (Citrullus lanatus) and/or maize (Zea mays) farms. We sampled soils from four different land use types within this farm: "native forest," "grassland," "watermelon farm," and "maize farm." We found that the land use type had a significant effect on the soil bacterial community structure at the class level, with the class Bacilli having significantly higher relative abundances in the forest sites and Gammaproteobacteria having significantly higher relative abundances in the maize sites than in the other land use types. These findings indicate that these bacterial classes may be sensitive to changes in soil ecosystems, and so further studies are required to investigate microbial indicators for the sustainable development of wetlands in sub-Saharan Africa.
\end{abstract}

\section{Introduction}

Soil microbes are important for soil productivity and nutrient cycling in both natural and agricultural ecosystems as they help plants to absorb nutrients by colonising their roots and decompose organic matter to provide soil nutrients and improve the soil structure. The diversity of soil microbial communities affects their resilience to heat and drought stress $[1,2]$ and is strongly influenced by soil characteristics such as $\mathrm{pH}$ [3] and carbon $(\mathrm{C})$ content $[4,5]$. However, little is known about the factors that control the soil microbial community structure in sub-Saharan African soils [6] despite an understanding of this being important for addressing the loss of fertility and soil degradation, both of which are serious issues in this region $[7,8]$.
In sub-Saharan Africa, there has been a large-scale conversion of natural ecosystems to agricultural lands in recent years, with a significant proportion of natural wetlands having been cultivated to produce crops such as maize (Zea mays). However, although these newly cultivated soils may be rich in nutrients and organic matter due to aeration of the soils inducing the mineralisation of organic nutrients, it has been suggested that they will lose their productivity within 25 years under continuous cultivation in the absence of organic/inorganic fertiliser application due to the loss of nutrients and structural stability [9]. Therefore, additional studies are required to investigate the potential changes that occur in soils when natural ecosystems are cultivated.

The aim of this research was to investigate the relationships among soil characteristics and microbial communities during the conversion of natural ecosystems into 
cultivated lands in Zambia and to link some basic soil chemical characteristics such as $\mathrm{pH}$, total carbon (TC), and total nitrogen (TN) to the changes in soil microbial diversity. We believe that a comparison of soil microbial communities in natural ecosystems before and after human intervention will provide some of the basic information that is needed to progress towards sustainable development in Zambia.

\section{Materials and Methods}

2.1. Soil Sampling Site. This experiment was performed in a semideveloped lowland farm located in the central region of Zambia (Figure S1), across which small-scale wetlands were distributed and the soil type was Haplic Lixisols [10, 11]. Soil samples (0-5 cm depth) were collected in February 2016 from 11 sites that were categorised into four different land use types: "native forest (f)" $(n=2)$, "grassland (g)" $(n=4)$, "watermelon farm $(\mathrm{w})$ " ( $n=3)$, and "maize farm $(\mathrm{m})$ " $(n=2)$ (Table S1). The forest sites were located in a Miombo woodland, which is considered a semiarid and biodiverse forest system that receives less than $1,100 \mathrm{~mm}$ of annual rainfall [12], and had a higher species richness than the grasslands in the study farm. According to the landowner, the maize farm has been continuously cultivated for at least 10 years, and the watermelon (Citrullus lanatus) farm was recently cultivated by developing a native land. The grassland sites were areas where forest had been cleared but the land had not yet been cultivated. The amount of rainfall from October 2015 to March 2016 in Lusaka was $770 \mathrm{~mm}$ (World Weather Online) while the amount of rainfall of average year was $>900 \mathrm{~mm}$ [13].

2.2. Soil Measurements. The soil moisture content of each soil sample was measured by oven-drying a fresh soil at $100^{\circ} \mathrm{C}$ for $>24$ hours and reweighing the dry soil. The $\mathrm{pH}$ of each soil sample was determined by mixing $5 \mathrm{~g}$ of air-dried soil with $12.5 \mathrm{~mL}$ of $10 \%$ potassium chloride solution $\left(\mathrm{pH}_{\mathrm{KCl}}\right)$ or deionised water $\left(\mathrm{pH}_{\mathrm{H}_{2} \mathrm{O}}\right)$, shaking for 30 minutes, and measuring the $\mathrm{pH}$ using a $\mathrm{pH}$ sensor (AS800; AS ONE Co., Japan). After measuring the soil $\mathrm{pH}_{\mathrm{KCl}}$, the solution was filtered through $1 \mu \mathrm{m}$ filter paper (Toyo Roshi Kaisha No. 5C filter paper; Toyo Roshi Kaisha, Ltd., Japan), and the inorganic-N (nitrate $\left[\mathrm{NO}_{3}^{-}-\mathrm{N}\right]$ and ammonium $\left[\mathrm{NH}_{4}^{+}-\mathrm{N}\right]$ ) contents were measured using a flow injection analyser (AQLA-700; Aqualab Co., Ltd., Japan). The TC and TN contents were measured using dried and finely ground soils with an organic elemental analyser (2400 Series II CHNS/O Elemental Analysis; PerkinElmer Co., USA).

\subsection{S rRNA Gene Analysis of the Soil Bacterial Community} Structure. To investigate the soil bacterial community structure in each land use type, DNA was extracted from airdried soils using the PowerSoil ${ }^{\circledR}$ DNA Extraction Kit (Mo Bio Laboratories, Carlsbad, CA, USA) following the manufacturer's protocol. The Ion Torrent system (Thermo Fisher Scientific K.K., Japan) was then used for $16 \mathrm{~S}$ rRNA analyses. The extracted DNA was amplified targeting the V2-4-8 and the V3-6 and 7-9 regions of the 16S rRNA gene using the Ion 16S Metagenomics Kit (Thermo Fisher Scientific K.K.,
Japan). The PCR cycling conditions were $600 \mathrm{sec}$ at $95^{\circ} \mathrm{C}$, followed by 25 cycles of $30 \mathrm{sec}$ at $95^{\circ} \mathrm{C}, 30 \mathrm{sec}$ at $58^{\circ} \mathrm{C}$, and $20 \mathrm{sec}$ at $72^{\circ} \mathrm{C}$, and a final extension of $420 \mathrm{sec}$ at $72^{\circ} \mathrm{C}$. The PCR products were quantified using the Qubit ${ }^{\mathrm{TM}} \mathrm{dsDNA} H S$ Assay Kit (Invitrogen, USA) and purified with the Ion Plus Fragment Library Kit (Thermo Fisher Scientific K.K., Japan), and the final lengths and concentrations of the amplicons were checked using the Bioanalyzer High Sensitivity DNA Kit (Agilent Technologies, USA). The library was then diluted to $50 \mathrm{pM}$ and loaded into the Ion 314 Chip (Thermo Fisher Scientific K.K., Japan) using the Ion Chef Instruments (Thermo Fisher Scientific K.K., Japan) with the Ion PGM ${ }^{\text {тм }}$ Hi-Q Chef Kit. DNA sequencing was conducted on the Ion PGM Sequencer (Thermo Fisher Scientific K.K., Japan) with the Ion PGM 400 Kit. The data were analysed online using Torrent Suite ${ }^{\mathrm{TM}}$ Software v5.0 (16S Metagenomics workflow v5.0).

2.4. Statistical Analysis. We investigated the effect of the land use type on the soil chemical and physical properties using oneway analysis of variance (ANOVA). To examine the effect of the land use type on the soil bacterial community structure, we calculated Shannon diversity indices at the class level and also used a permutational multivariate analysis of variance (MANOVA; "adonis" in the Vegan R library) and the BrayCurtis distance based on 999 permutations of the raw data, which is the default value. All statistical analyses were performed in $\mathrm{R}$ version 3.2.5 with a threshold $p$ value of 0.05 .

\section{Results and Discussion}

On average, 2,606-8,905 reads per soil sample were mapped to the 16S rRNA gene. Actinobacteria was the most dominant class across all land use types (Figure S2). Among the other classes that were present, Gammaproteobacteria had a higher relative abundance in the maize sites and Bacilli had a higher relative abundance in the forest sites.

The Shannon diversity index at the class level was, on average, higher in the maize sites $(2.35 \pm 0.18)$ than that in the other land use types $(1.64 \pm 0.08,1.76 \pm 0.34$, and $1.71 \pm$ 0.64 in the forest, grassland, and watermelon sites, resp.), but these differences were not significant. However, land use type had a significant effect on the bacterial community structure at the class level (MANOVA, $p<0.05$ ).

There was a significantly higher proportion of Gammaproteobacteria in the maize sites than in the other land use types $(p<0.05$; Figure $1(\mathrm{a}))$, with a total of 13 families occurring in the former, among which Chromatiaceae (4.0\%), Sinobacteraceae (5.3\%), and Xanthomonadaceae (3.0\%) were dominant, and Ectothiorhodospiraceae $(0.34 \%)$ and Halothiobacillaceae (1.6\%) were only found here. By contrast, the forest sites had relatively higher proportions of Chromatiaceae (1.9\%) and Bacilli (Figure 1(b)) than the other land use types, with the family Bacillaceae being abundant (12\%) within the class Bacilli, unlike in the other land use types. The family Paenibacillaceae was common in all soils, while the family Lactobacillaceae $(0.7 \%)$ was observed only in the grassland sites. 


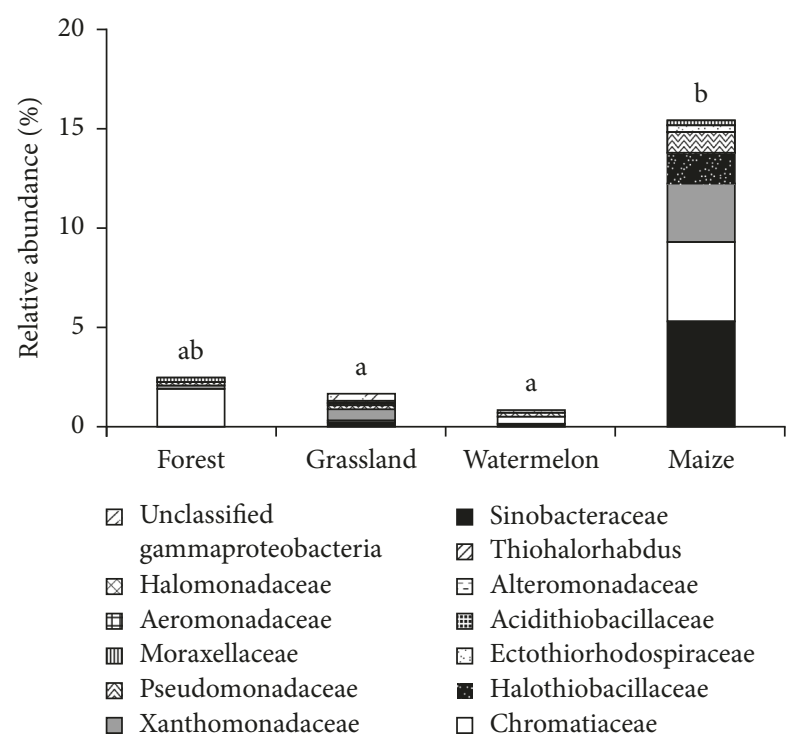

(a)

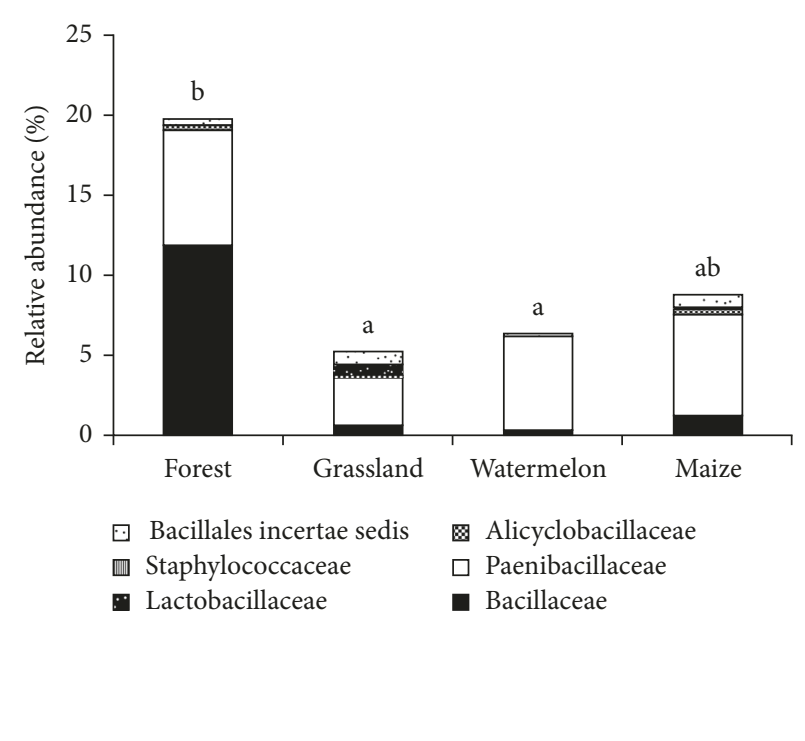

(b)

Figure 1: Relative abundances of the bacterial classes (a) Gammaproteobacteria and (b) Bacilli within the soil microbial community under different land use types. The different colours indicate different families within each class. Different lowercase letters above the bars indicate significant differences.

The soil $\mathrm{pH}_{\mathrm{H}_{2} \mathrm{O}}$ ranged from 4.9 to 6.0 and was significantly higher in the forest sites than that in the other land use types, while the soil $\mathrm{pH}_{\mathrm{KCl}}$ was also higher in the forest sites but was lower than the $\mathrm{pH}_{\mathrm{H}_{2} \mathrm{O}}$ overall (Table 1). The gravimetric soil moisture contents ranged between $13 \%$ and $16 \%$ and were not significantly different among the sites at the time of sampling. The $\mathrm{NO}_{3}^{-}-\mathrm{N}$ concentrations ranged from 7.8 to $34.2 \mathrm{mg} \cdot \mathrm{N} \cdot \mathrm{kg}^{-1}$ soil and were lowest in the grassland sites and highest in the maize sites, whereas the $\mathrm{NH}_{4}^{+}-\mathrm{N}$ concentrations ranged from 13.0 to $16.3 \mathrm{mg} \cdot \mathrm{N} \cdot \mathrm{kg}^{-1}$ soil with no significant difference among land use types (Figure 2). The amount of inorganic $\mathrm{N}$ varied markedly across the forest sites. Furthermore, the grassland soils predominantly contained $\mathrm{NH}_{4}^{+}-\mathrm{N}$, whereas the watermelon and maize sites mainly contained $\mathrm{NO}_{3}^{-}-\mathrm{N}$. There was no significant difference in TN among the land use types (Figure 3(a)), but TC was significantly higher in the forest sites than that in the other land use types (Figure 3(b)).

Soil microbial community structure is influenced by the land use and agricultural management practices. For example, Jangid et al. [14] previously found that Acidobacteria and Proteobacteria were less abundant in cropland soils than in forest soils in the USA, while the reverse was true for Firmicutes. It has previously been shown that Actinobacteria is the most abundant phylum $(>50 \%)$ in the very nutrientpoor savanna soil that occurs in South Africa's Kruger National Park [15], which is very similar to the findings of our study (Figure S2). By contrast, several large-scale surveys have repeatedly identified Acidobacteria and Proteobacteria as the most dominant bacterial phyla in soils across the world [3, 16-18], indicating that this high abundance of Actinobacteria may be a particular characteristic of subSaharan African soils, especially at natural sites. Zhou et al. [2] reported that Actinobacteria is often observed in a higher
TABLE 1: Mean \pm SD soil $\mathrm{pH}_{\mathrm{H}_{2} \mathrm{O}}, \mathrm{pH}_{\mathrm{KCl}}$, and their difference $(\Delta \mathrm{pH})$ for each land use type.

\begin{tabular}{lccc}
\hline Land use & $\mathrm{pH}_{\mathrm{H}_{2} \mathrm{O}}$ & $\mathrm{pH}_{\mathrm{KCl}}$ & $\Delta \mathrm{pH}$ \\
\hline Forest & $6.00 \pm 0.47 \mathrm{~b}$ & $5.14 \pm 0.27 \mathrm{~b}$ & $0.86 \pm 0.20 \mathrm{ab}$ \\
Grassland & $5.17 \pm 0.36 \mathrm{a}$ & $4.06 \pm 0.08 \mathrm{a}$ & $1.11 \pm 0.29 \mathrm{~b}$ \\
Watermelon & $5.13 \pm 0.79 \mathrm{a}$ & $4.21 \pm 0.45 \mathrm{a}$ & $0.92 \pm 0.37 \mathrm{ab}$ \\
Maize & $4.91 \pm 0.32 \mathrm{a}$ & $4.28 \pm 0.25 \mathrm{a}$ & $0.63 \pm 0.07 \mathrm{a}$ \\
\hline
\end{tabular}

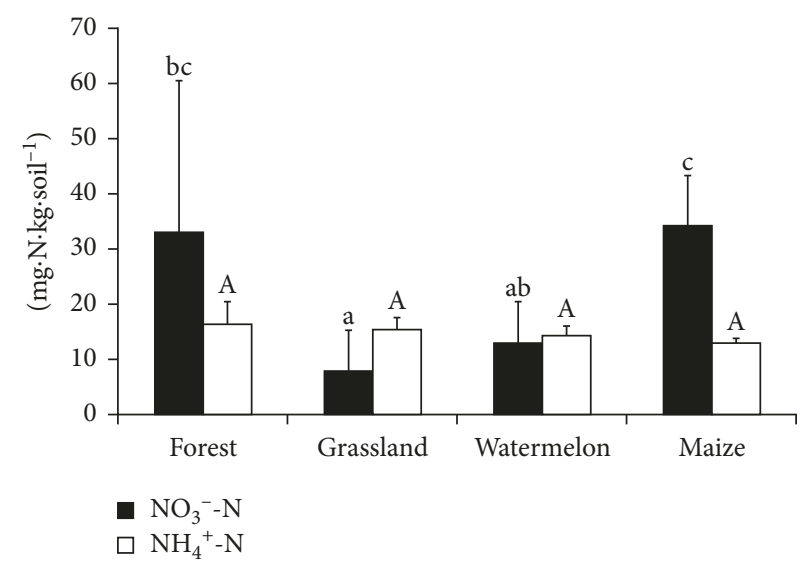

Figure 2: Mean \pm SD soil contents of $\mathrm{NO}_{3}^{-}-\mathrm{N}$ and $\mathrm{NH}_{4}^{+}-\mathrm{N}$ under different land use types. Different letters above the bars indicate significant differences in $\mathrm{NO}_{3}^{-}-\mathrm{N}$ (lowercase letters) and $\mathrm{NH}_{4}^{+}-\mathrm{N}$ (uppercase letters) among land use types (one-way ANOVA, $p<0.05)(n=2,4,3$, and 2 for forest, grassland, watermelon, and maize sites, resp.).

abundance in forest soils in Africa, particularly when the soils are under drought stress, indicating that drought stress may be one of the factors controlling the abundance of 


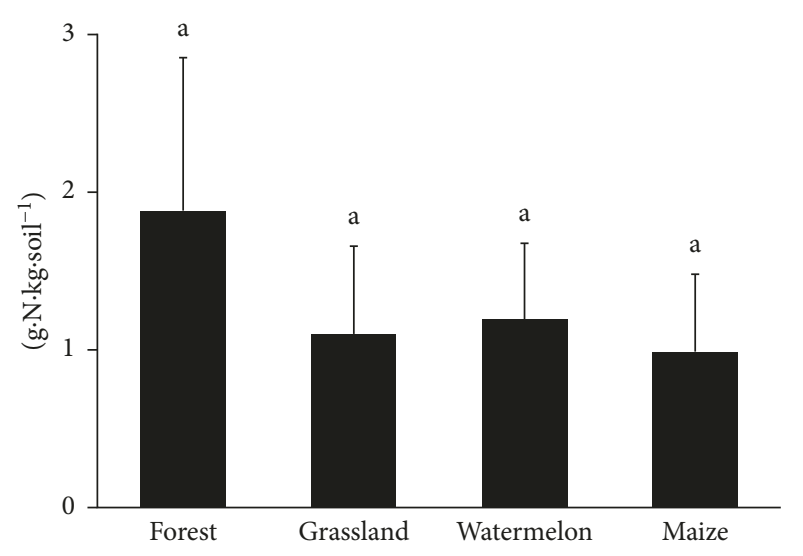

(a)

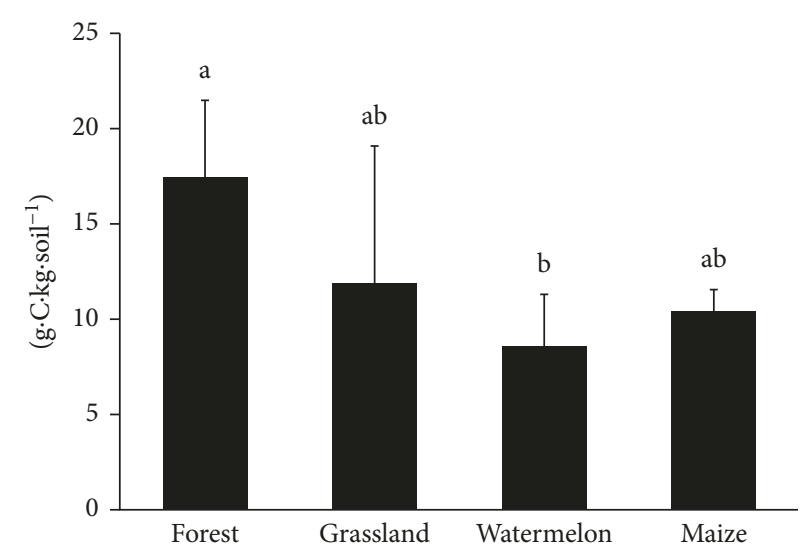

(b)

Figure 3: Mean \pm SD (a) total nitrogen and (b) total carbon contents of the soil under different land use types. Different lowercase letters above the bars indicate significant differences among the land use types (one-way ANOVA, $p<0.05)(n=2,4,3$, and 2 for the forest, grassland, watermelon, and maize sites, resp.).

Actinobacteria, although further studies are required to confirm this.

In this study, TC was significantly lower at the cultivated sites (Figure 3(b)), which may explain the different soil microbial community structures that were observed across land use types as it has been suggested that organic C contents have a strong effect on the microbial community structure [19]. Comparison of the Shannon diversity indices based on the soil microbial classes indicated that microbial diversity was higher under intensive cultivation (the maize sites), however, indicating that the cultivation of natural soils does not necessarily reduce the diversity of soil microbes. Similarly, Hartmann et al. [20] suggested that long-term organic farming (low-input agricultural systems) did not result in a higher diversity of soil microbes than conventional farming and concluded that organisms adapt to the low-nutrient environment in organically farmed soils leading to a large shift in the soil microbial communities. Thus, the increase in soil microbial diversity that was observed in cultivated soils in the present study may have been due to the increased input of nutrients from chemical fertilisers. However, it should be noted that the number of replicates per land use type was small in the present study, and the variability within land use types was large. Therefore, future studies should investigate the specific functional changes in soil microbial communities across land use types.

The relative abundance of Gammaproteobacteria was significantly higher in the maize sites, which were characterised by a low $\mathrm{pH}$ and higher $\mathrm{NO}_{3}^{-}-\mathrm{N}$ concentrations. The main families within this class were Chromatiaceae, Sinobacteraceae, and Xanthomonadaceae, all of which have been reported as only being found in agricultural soils and not natural grassland and forest soils [21]. The abundance of Gammaproteobacteria has previously been associated with both low pH (3.8) [22] and the amount of $\mathrm{NO}_{3}^{-}-\mathrm{N}$ in soils [23] and so may be an indicator of $\mathrm{NO}_{3}^{-}-\mathrm{N}$-enriched soils.

The class Bacilli (phylum Firmicutes) had a significantly higher relative abundance in the forest sites. Previous studies have shown that the abundance of Bacillus is greater in both grassland and cultivated soils than that in forest soils, with Firmicutes constituting no more than $5 \%$ of microbes in forest soils $[24,25]$. The majority of Firmicutes are aerobic or facultatively anaerobic, and they also possess Gram-positivetype cell-wall structures that form endospores [26], all of which can be an advantage for surviving the dry season in the sub-Saharan region [15]. Bacillus has several ecosystem functions, including the degradation of soil organic matter and playing important roles in the $\mathrm{N}$ cycle such as nitrification, denitrification, and $\mathrm{N}$ fixation. In our study, the forest sites had higher TN and TC contents than the other sites (Figure 3), suggesting that this bacterial class may be related to the maintenance of some $\mathrm{N}$ cycle-related processes. Some Bacilli, such as Bacillus subtilis and B. cereus, are also known for their roles as beneficial rhizobacteria that promote plant growth or protect plants from pathogens [27].

Leff et al. [28] previously found that the proportion of Gammaproteobacteria in the soil significantly increases with increasing $\mathrm{N}$ inputs, which may explain the increased abundance of Gammaproteobacteria in the maize sites compared with the forest sites in the present study as chemical fertiliser has been applied at the former. The increase in Gammaproteobacteria at these sites may also be explained by differences in the $\mathrm{C}$ cycle dynamics. Cleveland et al. [29] reported that dissolved organic matter inputs drive high rates of soil respiration in the soil bacterial community, particularly among members of the class Gammaproteobacteria. Therefore, the lower soil C levels in the maize sites may have been due to increased soil respiration rates with cultivation, although the availability of $\mathrm{C}$ would decrease when soil C was completely depleted.

\section{Conclusion}

This research examined the effects of land use changes from forest to grassland lands and grassland to cultivated lands on soil bacterial communities in a semideveloped farm in Zambia. We found that soil bacterial diversity was higher in the maize sites than that in the natural sites. In addition, the 
relative abundance of the bacterial class Bacilli was higher in the forest sites, while that of the class Gammaproteobacteria was higher in the intensively cultivated maize sites compared with the other land use types. These findings indicate that these classes may be sensitive to changes in soil ecosystems and responding to the addition of nutrients such as nitrogen. Soil degradation as a result of cultivation is becoming severe in sub-Saharan Africa, but there have been few reports to date on soil microbial communities in this region. Therefore, further basic studies are required to better understand these soil microbial communities and how they vary with the land use type.

\section{Conflicts of Interest}

The authors declare that they have no conflicts of interest.

\section{Acknowledgments}

This work was financially supported by the Global Leadership Training Programme in Africa (GLTP) from United Nations University. The authors would like to thank Enago (http://www.enago.jp) for the English language review.

\section{Supplementary Materials}

Figure S1: location of each sampling site measured by the Global Positioning System (GPS) (eTrex 20; GARMIN Inc., USA) and shown using Google Earth (ver. 7.1.8.3036., Google Inc., USA). The sampling sites were categorised into four land use types: "native forest (f)," "grassland (g)," "watermelon farm (w)," and "maize farm (m)." The numbers indicate different sampling sites. Brief descriptions of each sampling site are provided in Table S1. Figure S2: relative abundance of bacterial classes in the soil sampled from each site based on $16 \mathrm{~S}$ rRNA gene sequencing. The letters indicate the land use types $(\mathrm{f}=$ forest, $\mathrm{g}=$ grassland, $\mathrm{w}=$ watermelon farm, and $\mathrm{m}=$ maize farm), and the numbers alongside the letters represent the replicates for each land use type. Classes with an abundance of $<2 \%$ were grouped as "others." Table S1: descriptions of each site based on interviews with the local farmer and a field survey. See Figure S1 for a map of the sampling points. (Supplementary Materials)

\section{References}

[1] V. Tardy, O. Mathieu, J. Lévêque et al., "Stability of soil microbial structure and activity depends on microbial diversity," Environmental Microbiology Reports, vol. 6, no. 2, pp. 173-183, 2014.

[2] X. Zhou, D. Fornara, M. Ikenaga, I. Akagi, R. Zhang, and Z. Jia, "The resilience of microbial community under drying and rewetting cycles of three forest soils," Frontiers in Microbiology, vol. 7, 2016.

[3] C. L. Lauber, M. Hamady, R. Knight, and N. Fierer, "Pyrosequencing-based assessment of soil $\mathrm{pH}$ as a predictor of soil bacterial community structure at the continental scale," Applied and Environmental Microbiology, vol. 75, no. 15, pp. 5111-5120, 2009.

[4] C. Lazcano, M. Gómez-Brandón, P. Revilla, and J. Domínguez, "Short-term effects of organic and inorganic fertilizers on soil microbial community structure and function," Biology and Fertility of Soils, vol. 49, no. 6, pp. 723-733, 2013.

[5] C. A. Creamer, A. B. de Menezes, E. S. Krull, J. Sanderman, R. Newton-Walters, and M. Farrell, "Microbial community structure mediates response of soil $\mathrm{C}$ decomposition to litter addition and warming," Soil Biology and Biochemistry, vol. 80, pp. 175-188, 2015.

[6] S. Wild, "Quest to map Africa's soil microbiome begins," Nature, vol. 539, no. 7628, p. 152, 2016.

[7] FAO, Land and Environmental Degradation and Desertification in Africa, FAO Corporate Document Repository, Rome, Italy, 1995.

[8] L. R. Oldeman, R. T. A. Hakkeling, and W. G. Sombroek, World Map of the Status of Human-Induced Soil Degradation: An Explanatory Note, Wageningen, Netherlands, and Nairobi, Kenya: International Soil Reference and Information Centre and United Nations Environment Programme, Nairobi, Kenya, 1991.

[9] T. Raussen, A. E. Daka, and L. Bangwe, Dambos in Eastern Province: Their Agroecology and Use, Department of Agriculture, Chipata, Zambia, 1995.

[10] FAO, Luangwa Valley Conservation and Development Project: Report on Project Results, Conclusions and Recommendations, FO: DP/ZAM/68/510 Terminal Report, Food and Agriculture Organization of the United Nation, Rome, Italy, 1973.

[11] IUSS Working Group, World Reference Base for Soil Resources 2014, International Soil Classification System for Naming Soils and Creating Legends for Soil Maps, FAO Update 2015, Rome, Italy, 2015.

[12] E. N. Chidumayo, "Species structure in Zambian Miombo woodland," Journal of Tropical Ecology, vol. 3, no. 2, pp. 109-118, 1987.

[13] J. M. Kampata, B. P. Parida, and D. B. Moalafhi, "Trend analysis of rainfall in the headstreams of the Zambezi River Basin in Zambia," Physics and Chemistry of the Earth, Parts $A / B / C$, vol. 33, no. 8, pp. 621-625, 2008.

[14] K. Jangid, M. A. Williams, A. J. Franzluebbers et al., "Relative impacts of land-use, management intensity and fertilization upon soil microbial community structure in agricultural systems," Soil Biology and Biochemistry, vol. 40, no. 11, pp. 2843-2853, 2008.

[15] S. Rughöft, M. Herrmann, C. S. Lazar et al., "Community composition and abundance of bacterial, archaeal and nitrifying populations in savanna soils on contrasting bedrock material in Kruger National Park, South Africa," Frontiers in Microbiology, vol. 7, 2016.

[16] P. H. Janssen, "Identifying the dominant soil bacterial taxa in libraries of 16S rRNA and 16S rRNA genes," Applied and Environmental Microbiology, vol. 72, no. 3, pp. 1719-1728, 2006.

[17] H. Nacke, A. Thürmer, A. Wollherr et al., "Pyrosequencingbased assessment of bacterial community structure along different management types in German forest and grassland soils," PLoS One, vol. 6, no. 2, Article ID e17000, 2011.

[18] S. M. Prober, J. W. Leff, S. T. Bates et al., "Plant diversity predicts beta but not alpha diversity of soil microbes across grasslands worldwide," Ecology Letters, vol. 18, no. 1, pp. 85-95, 2015.

[19] K. L. Steenwerth, L. E. Jackson, F. J. Calderón, M. R. Stromberg, and K. M. Scow, "Soil microbial community composition and land use history in cultivated and grassland ecosystems of coastal California," Soil Biology and Biochemistry, vol. 34, no. 11, pp. 1599-1611, 2002. 
[20] M. Hartmann, B. Frey, J. Mayer, P. Mäder, and F. Widmer, "Distinct soil microbial diversity under long-term organic and conventional farming," The ISME Journal, vol. 9, no. 5, pp. 1177-1194, 2015.

[21] E. E. Kuramae, E. Yergeau, L. C. Wong, A. S. Pijl, J. A. Veen, and G. A. Kowalchuk, "Soil characteristics more strongly influence soil bacterial communities than land-use type," FEMS Microbiology Ecology, vol. 79, no. 1, pp. 12-24, 2012.

[22] L. F. W. Roesch, R. R. Fulthorpe, A. Riva et al., "Pyrosequencing enumerates and contrasts soil microbial diversity," ISME Journal, vol. 1, no. 4, pp. 283-290, 2007.

[23] A. C. Hamm, M. Tenuta, D. O. Krause, K. H. Ominski, V. L. Tkachuk, and D. N. Flaten, "Bacterial communities of an agricultural soil amended with solid pig and dairy manures, and urea fertilizer," Applied Soil Ecology, vol. 103, pp. 61-71, 2016.

[24] A. K. A. Suleiman, L. Manoeli, J. T. Boldo, M. G. Pereira, and L. F. W. Roesch, "Shifts in soil bacterial community after eight years of land-use change," Systematic and Applied Microbiology, vol. 36, no. 2, pp. 137-144, 2013.

[25] P. H. Rampelotto, A. Ferreira, S. de, A. D. M. Barboza, and L. F. W. Roesch, "Changes in diversity, abundance, and structure of soil bacterial communities in Brazilian Savanna under different land use systems," Microbial Ecology, vol. 66, no. 3, pp. 593-607, 2013.

[26] N. A. Logan and P. D. Vos, "Bacillaceae," Bergey's Manual of Systematics of Archaea and Bacteria, John Wiley and Sons, Inc., in Association with Bergey's Manual Trust, 2015.

[27] D. K. Choudhary and B. N. Johri, "Interactions of Bacillus spp. and plants-with special reference to induced systemic resistance (ISR)," Microbiological Research, vol. 164, no. 5, pp. 493-513, 2009.

[28] J. W. Leff, S. E. Jones, S. M. Prober et al., "Consistent responses of soil microbial communities to elevated nutrient inputs in grasslands across the globe," Proceedings of the National Academy of Sciences, vol. 112, no. 35, pp. 10967-10972, 2015.

[29] C. C. Cleveland, D. R. Nemergut, S. K. Schmidt, and A. R. Townsend, "Increases in soil respiration following labile carbon additions linked to rapid shifts in soil microbial community composition," Biogeochemistry, vol. 82, no. 3, pp. 229-240, 2007. 

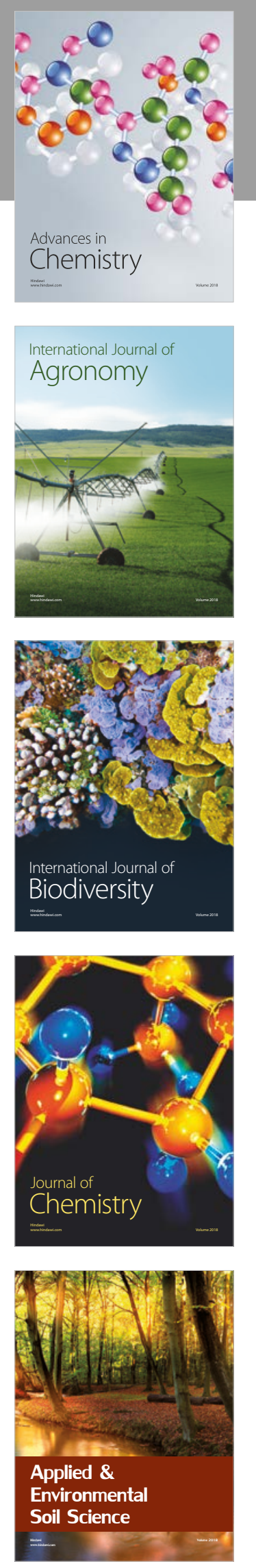

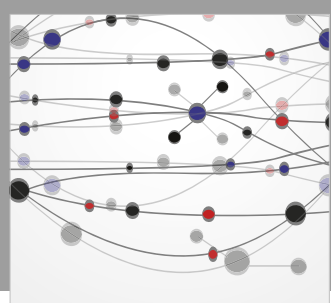

The Scientific World Journal

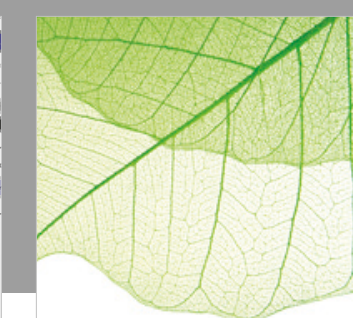

Journal of Botany

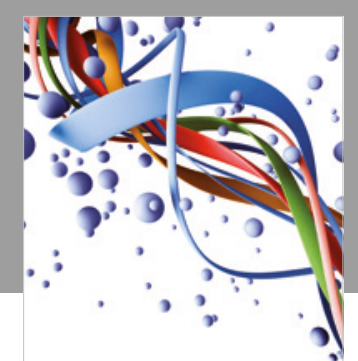

Scientifica

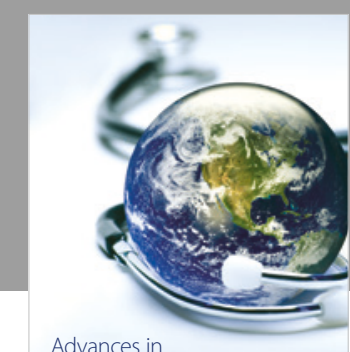

Public Health

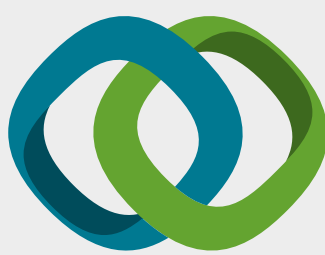

Hindawi

Submit your manuscripts at

www.hindawi.com
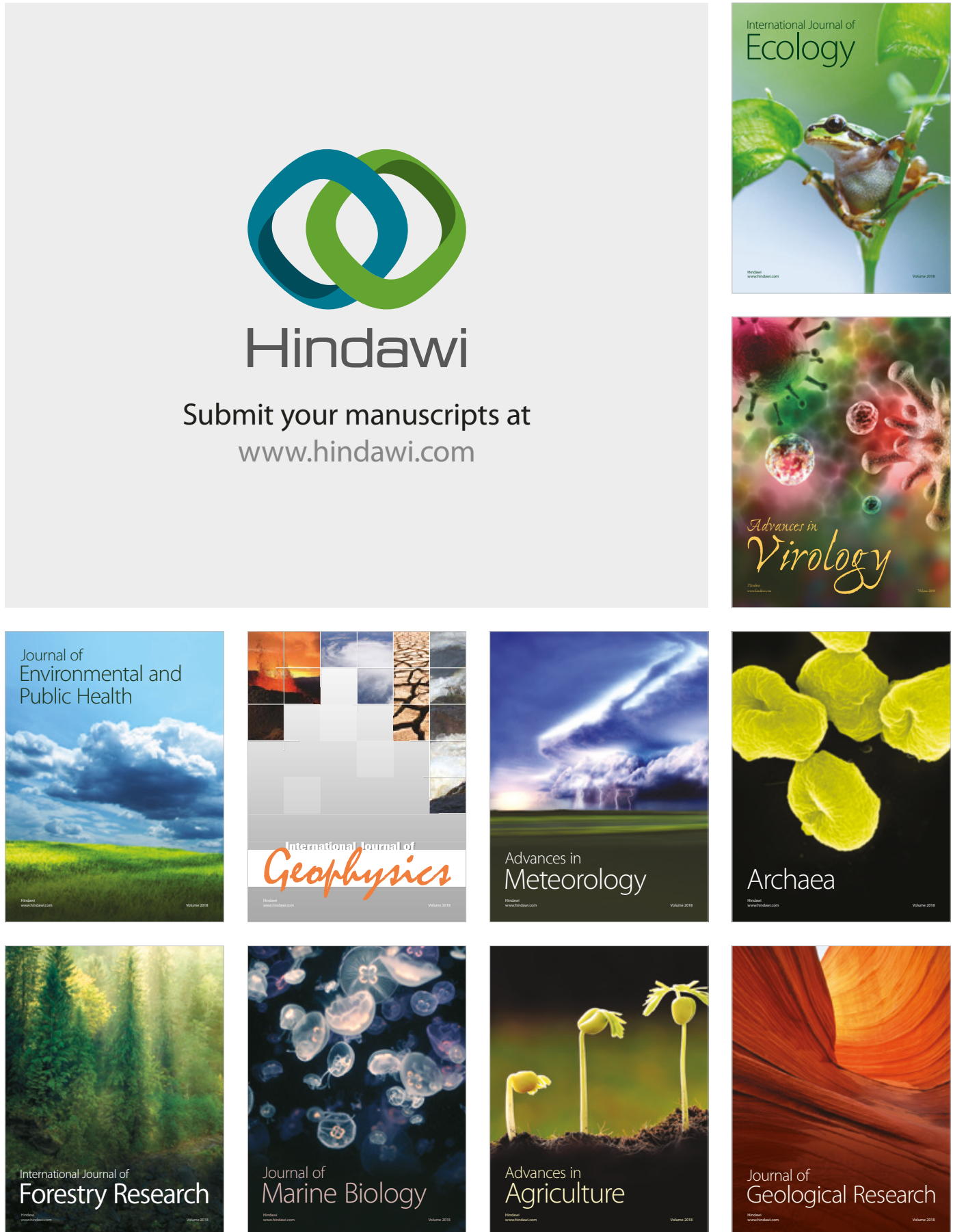

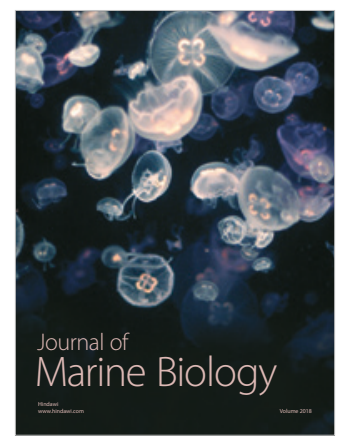

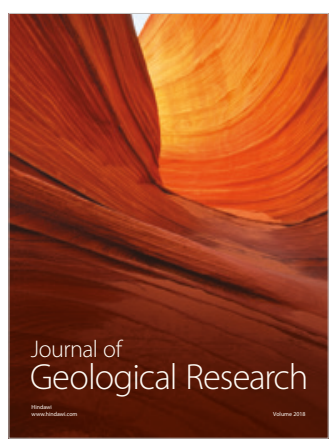

